\title{
RELIGIOUSITY COMMITMENT DALAM MEMODERASI HUBUNGAN BRAND AWARENESS TERHADAP NIAT PEMBELIAN
}

\author{
Mohammad Fakhruddin Mudzakkir \\ Email : fakhruddin@unikama.ac.id \\ Iva Nurdiana Nurfarida \\ Email : iva_noerdiana@yahoo.com
}

\begin{abstract}
Abstrak: Penelitian ini bertujuan untuk mengetahui 1). Pengaruh brand awareness terhadap niat pembelian pada toko roti merk Islami, 2). Pengaruh religousity commitment terhadap niat pembelian pada toko roti merk Islami, 3). Peranan religousity commitment sebagai variabel moderator yang dapat memperkuat pengaruh brand awareness terhadap niat pembelian pada toko roti merk Islami. Jenis penelitian adalah survey. Populasinya adalah konsumen yang melakukan pembelian pada 3 toko roti Merk Islami di Kota/Kabupaten Malang, yaitu Toko Roti Amanah, Toko Roti As Sunnah, dan Toko Roti Madinah. Teknik pengambilan sampelnya adalah accidental sampling. Penelitian ini menggunakan metode analisis Moderated Regression Analysis. Hasil analisis menunjukkan variabel brand awareness dan religousity commitment berpengaruh positif dan signifikan terhadap niat pembelian. Religousity commitment tidak dapat berperan sebagai variabel moderasi terhadap hubungan brand awareness terhadap niat pembelian merk produk Islami
\end{abstract}

Kata kunci: awareness, religousity commitment, niat pembelian

\section{PENDAHULUAN}

Merk mempunyai dampak sebagai pembeda yang penting antar produk, sehingga konsumen lebih mudah mengenali produk yang ditawarkan oleh produsen. Agama memberikan keyakinan dan nilai yang mengarahkan perilaku seseorang, (Delener, 1994). Adanya aturan dan larangan dalam agama mempengaruhi perilaku seseorang dalam menentukan pilihan, Mokhlis (2010). Agama mewajibkan bagi pemeluknya untuk menjalankan apa yang diperintahkan dan tidak melakukan apa yang dilarang Hal penting yang semakin disadari oleh retailer dalam membedakan produknya dengan produk lainnya adalah penggunaan merk Islami untuk pemberian nama produknya dengan menggunakan nama Islam. Bagi retailer penggunaan nama Islam memudahkan konsumen untuk mengenali dan mengingat produk tersebut.

Mohammad Fakhruddin Mudzakkir, adalah Dosen Prodi Manajemen Universitas Kanjuruhan Malang

Iva Nurdiana, adalah Dosen Prodi Manajemen Universitas Kanjuruhan Malang 
Dalam konteks pemasaran, merk Islami tidak terlepas dari pandangan bahwa komunitas muslim merupakan suatu segmen tersendiri. Segmen agama dianggap mempunyai perilaku tertentu yang dapat diprediksi dan dijelaskan (Sandikci 2011). Esso (2004) menjelaskan bahwa keputusan pembelian konsumen dapat di tentukan oleh tingkat religiusitas. Namun demikian, menurut Scoot (2003), membuktikan bahwa religiusitas memberikan pengaruh yang paling rendah terhadap perilaku konsumen dalam menentukan keputusan pembelian. Dalam konteks ini, masih belum ada kejelasan apakah konsumsi barang dan jasa dipengaruhi oleh tingkat religiusitas. Penelitian ini berusaha mengungkapkan hubungan religiusitas dalam memoderasi kesadaran merk terhadap niat pembelian.

\section{TINJAUAN PUSTAKA}

\section{Brand awareness}

Brand awareness merupakan kemampuan konsumen untuk mengingat jejak merk yang ada di memory konsumen dalam berbagai kondisi, Rossiter and Percy (1987) dalam Keller (1993). Menurut Terence A Shimp (2003), kesadaran merek merupakan kemampuan sebuah merek untuk muncul dalam benak konsumen ketika mereka sedang memikirkan kategori produk tertentu.

Bagi konsumen untuk mengetahui tingkat brand awareness adalah sejauh mana konsumen dapat mengingat kembali suatu merk dengan bantuan, berikutnya adalah pengingatan tanpa bantuan, artinya bahwa konsumen dapat menyebut nama suatu merk suatu produk pada kategori tertentu tanpa dibantu, tingkatan berikutnya adalah top of mind yaitu konsumen dapat menyebutkan nama merk barang pertama kali pada kategori produk tertentu. Hoeffler \& Keller (2002) menjelaskan bahwa suatu produk dapat disebut mempunyai brand awareness yang tinggi jika mempunyai unsur kedalaman dan keluasan, kedalaman berarti konsumen dapat mengingat nama merk produk dengan mudah adapun keluasan adalah nama merk muncul dibenak konsumen bersamaan ketika konsumen membeli barang.

Peran penting brand awareness terhadap pembelian disebabkan konsumen cenderung membeli merk produk yang sudah familiar dan dikenal (Macdonald \& Sharp, 2000). Pertimbangan alternatif produk didasarkan sejauh mana nama-nama merk diingat kembali untuk menjadi pertimbangan dalam pengambilan keputusan pembelian. Ketika melakukan pembelian konsumen akan mengevaluasi beberapa alternatif merk yang sudah dikenalnya sehingga mempengaruhi pengambilan keputusan pembelian

\section{Religousity Commitment}

Beberapa perilaku konsumsi terkait religiusitas adalah dilarangnya orang islam untuk makan daging babi atau bagi umat hindu untuk makan daging sapi. Religiusitas merupakan dogma yang harus diamalkan bagi bagi pemeluknyapemelukya.

Religiousity commitment (religiosity) merujuk pada tingkatan yang dimiliki seseorang terhadap nilai-nilai religiusitas, kepercayaan dan praktek religius dalam kehidupan sehari-hari, (Worthington et al., 2003). Johnson et al. (2001) religiusitas adalah sejauh mana individu berkomitmen dan mengakui ajaran agamanya. Seseorang yang mempunyai religiusitas yang tinggi cenderung 
mematuhi aturan yang ditetapkan dalam agama, misalnya beribadah secara teratur dan berkomitmen terhadap kelompok agamanya.

Beberapa penelitian terdahulu yang menguji pengaruh religiusitas terhadap perilaku berbelanja adalah Sood \& Nasu, (1995) yang menyimpilkan bahwa terdapat perbedaan pada perilaku konsumen pada masyarakat dengan religiusitas tinggi dan dengan religiusitas rendah. Studi yang dilakukan oleh McDaniel and Burnett (1990) menemukan bahwa religiusitas berpengaruh atas penilaian konsumen tentang atribut toko swalayan. Pada studi ini religiusitas dibagi menjadi dua perspektif yaitu religiousity commitment dan religious affiliation. Religiousity commitment diukur melalui kognitif konsumen dan religious affiliation diukur melalui perilaku religiusitas konsumen keduanya menunjukkan hasil bahwa terdapat pengaruh pada berbagai aspek kriteria evaluasi pembelian retail. Konsumen dengan tingkat religiusitas kognitif tinggi lebih mementingkan keramahan penjual, efisiensi berbelanja dan kualitas produk pada toko ritel dari pada konsumen yang mempunyai religiusitas kognitif rendah. Adapun konsumen dengan religious affiliation lebih mementingkan keramahan penjual dan ketersediaan pembayaran secara kredit.

\section{Niat Pembelian}

Perilaku konsumen dapat bersifat terbuka atau tersembunyi, perilaku yang tersembunyi disebut sebagai niat, Mowen dan Minor (2002) mendefinisikan niat berperilaku (behavioral intention) sebagai niat konsumen untuk berperilaku tertentu mempertimbangkan pembelian, karakter dan penggunaan barang. Theory of Reason Action yang dikembangkan oleh Fishbein dan Ajzen (dalam Kardes, 2001) menyatakan bahwa perilaku seseorang ditentukan oleh niat berperilaku. Theory of Reason Action yang diaplikasikan dalam perilaku konsumen, perilaku pembelian dipengaruhi oleh niat (intention) yang disebabkan oleh sikap terhadap perilaku (attitude towards behavior) dan norma-norma subyektif (subjective norm) (Dharmmesta, 2002). Pada studi ini sikap tentang brand awareness digunakan untuk memprediksi niat untuk melakukan pembelian Menurut landasan teori brand awareness, religiousity commitment dan niat pembelian maka dapat disusun kerangka konseptual sebagai berikut :

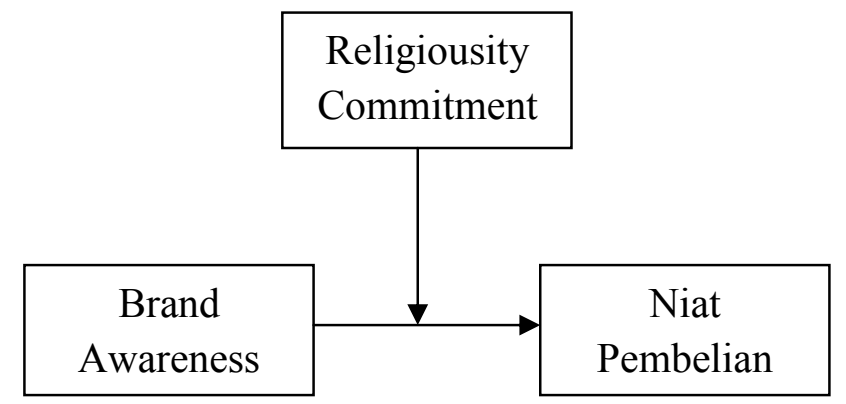

Gambar 1. Kerangka Konseptual Penelitian

Berdasarkan literature review di atas, maka hipotesis pada penelitian ini adalah sebagai berikut :

1. Brand awareness berpengaruh positif dan signifikan terhadap niat pembelian pada toko roti merk Islami. 
2. Religiousity commitment berpengaruh positif dan signifikan terhadap niat pembelian pada pada toko roti merk Islami.

3. Religousity commitment berperan sebagai variabel moderator yang dapat memperkuat pengaruh brand awareness terhadap niat pembelian pada toko roti merk Islami.

\section{METODA PENELITIAN}

Populasi dalam penelitian ini adalah konsumen yang melakukan pembelian di 3 (tiga) toko roti di Kota/Kab. Malang yaitu Toko Roti As Sunnah, Toko Roti Amanah, dan Toko Roti Madinah. Penelitian ini menarik sampel dengan menggunakan metode atau teknik accidental sampling, dengan jumlah sampel sebanyak 75 responden. Metode pengumpulan data menggunakan kuesioner, dengan variabel penelitian sebanyak tiga variabel ; 1 variabel independen yaitu brand awareness, 1 variabel dependent yaitu niat pembelian dan 1 variabel moderator yaitu religousity commitment.

Teknik analisis pada penelitian ini menggunakan teknik analisis Moderated Regression Analysis atau uji interaksi merupakan aolikasi khusus regresi linier berganda dimana dalam persamaan regresinya mengandung unsur interaksi (perkalian dua atau lebih variabel independen). Variabel perkalian disebut variabel moderator karena menggambarkan pengaruh moderating variabel terhadap hubungan variabel independen dengan variabel dependent.

\section{Uji Instrumen}

Uji validitas dilakukan untuk melihat valid tidaknya masing-masing instrumen yang digunakan dalam variabel penelitian. Adapun hasil uji validitas dengan menggunakan analisis faktor adalah sebagai berikut :

\begin{tabular}{|l|c|c|c|}
\hline \multicolumn{1}{|c|}{ Item } & KMO & Signifikansi & Keterangan \\
\hline Brand awareness $(\mathrm{X} 1)$ & 0,599 & 0,005 & Valid \\
\hline $\begin{array}{l}\text { Religiousity commitment } \\
\text { (X2) }\end{array}$ & 0,613 & 0,000 & Valid \\
\hline Niat Pembelian (Y) & 0,543 & 0,000 & Valid \\
\hline
\end{tabular}

Tabel 1. Data Diolah, 2015

Berdasarkan tabel 1 diatas maka semua instrumen valid karena mempunyai nilai Kaiser Meyel Olkin (KMO) $>0,50$ dengan tingkat signifikansi $<0,05$, sehingga semua indikator dalam penelitian dapat digunakan dalam analisis lebih lanjut.

\begin{tabular}{|l|c|c|}
\hline \multicolumn{1}{|c|}{ Item } & $\begin{array}{c}\text { Cronbach } \\
\text { Alpha }\end{array}$ & Keterangan \\
\hline Brand awareness (X1) & 0,734 & Valid \\
\hline $\begin{array}{l}\text { Religiousity commitment } \\
\text { (X2) }\end{array}$ & 0,723 & Valid \\
\hline Niat Pembelian (Y) & 0,710 & Valid \\
\hline
\end{tabular}

Tabel 2. Data Diolah, 2015 
Uji reliabilitas dari instrumen penelitian dengan mempertimbangkan besarnya koefesien reliabilitas. Sesuai dengan hasil analisa data primer maka instrumen yang digunakan dalam penelitian memiliki hasil uji yang menunjukkan bahwa angka cronbach alpha diatas 0,6 (Ghozali, 2005), yaitu sebesar 0,737 artinya dari uji reliabilitas dapat dikatakan bahwa seluruh variabel yang digunakan dalam penelitian ini adalah reliabel.

\section{HASIL PENELITIAN}

Menurut Liana (2009) Moderated Regression Analysis (MRA) atau uji interaksi merupakan aplikasi khusus regresi berganda linear dimana dalam persamaan regresinya mengandung unsur interaksi (perkalian dua atau lebih variabel independen). Variabel perkalian merupakan variabel moderator karena berfungsi menguatkan atau melemahkan hubungan antara variabel independen terhadap variabel dependen. Untuk mengetahui bahwa variabel tertentu dapat menjadi variabel moderasi, harus memenuhi taraf signifikansi $<0,05$

Berdasarkan pengolahan hasil dengan SPSS 20 didapat hasil sebagai berikut

\section{Coefficients}

\begin{tabular}{|c|c|c|c|c|c|c|}
\hline & \multirow[t]{2}{*}{ Model } & \multicolumn{2}{|c|}{$\begin{array}{c}\text { Unstandardized } \\
\text { Coefficients }\end{array}$} & \multirow{2}{*}{$\begin{array}{c}\text { Standardized } \\
\text { Coefficients }\end{array}$} & \multirow[t]{2}{*}{$\mathrm{t}$} & \multirow[t]{2}{*}{ Sig. } \\
\hline & & B & $\begin{array}{l}\text { Std. } \\
\text { Error }\end{array}$ & & & \\
\hline \multirow{4}{*}{1} & (Constant) & .891 & .242 & & 3.682 & .000 \\
\hline & brand_awarens & .159 & .059 & .197 & 2.713 & .008 \\
\hline & religi_commitn & .668 & .074 & .776 & 9.026 & .000 \\
\hline & brand_awarnsxreligi_commitn & -.005 & .013 & -.034 & -.378 & .707 \\
\hline
\end{tabular}

Dari hasil pengolahan data diatas menunjukkan bahwa brand awareness dan religiousity commitment masing-masing berpengaruh positif dan signifikan terhadap niat pembelian. Adapun variabel interaksi brand awareness dikalikan variabel religiousity commitment mempunyai signifikansi $>0,05$ sehingga variabel religiousity commitment tidak dapat berperan sebagai variabel moderasi.

\section{Hasil Uji Hipotesis}

\section{Uji F}

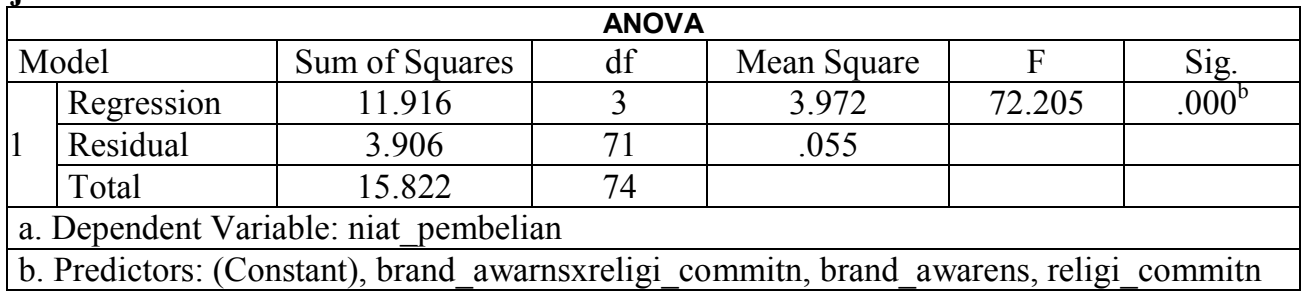

Uji F dilakukan untuk melakukan uji kelayakan model sebagai syarat dapat dilakukannya uji hipotesis. Model penelitian ini dinyatakan layak apabila nilai signifikansinya $<0,05$. Hasil uji $\mathrm{F}$ dapat dilihat dari tabel diatas, terlihat nilai. 
signifikansinya sebesar 0,000 atau $<0,05$, ini artinya model layak dan dapat diteruskan dengan uji hipotesis.

\section{Uji Hipotesis Secara Parsial (Uji t)}

- Uji signifikan t-test antara brand awareness (X1), terhadap niat pembelian (Y).

Hasil analisis di peroleh thitung brand awareness (X1), sebesar 2,713 pada tingkat probabilitas 0,008 . Hasil pengujian diperoleh harga probabilitas hitung $0,008<0,05$ atau probabilitas hitung $<$ level of significance $(\alpha)$ sehingga $\mathrm{H} 0$ ditolak, hal ini berarti bahwa ada pengaruh signifikan dan positif antara brand awareness (X1) terhadap niat pembelian (Y)

- Uji signifikan t-test antara religiousity commitment (X2), terhadap niat pembelian (Y).

Hasil analisis di peroleh thitung religiousity commitment (X2) sebesar 9,026 pada tingkat probabilitas 0,000 . Hasil pengujian diperoleh harga probabilitas hitung $0,000<0,05$ atau probabilitas hitung $<$ level of significance $(\alpha)$ sehingga $\mathrm{H} 0$ ditolak, hal ini berarti bahwa ada pengaruh signifikan dan positif antara religiousity commitment $(\mathrm{X} 2)$ terhadap niat pembelian $(\mathrm{Y})$

- Uji signifikan t-test antara (brand awareness $X$ religiousity commitment) terhadap niat melakukan pembelian $(\mathrm{Y})$.

Hasil analisis di peroleh thitung (brand awareness $\mathrm{X}$ religiousity commitment) sebesar $-0,378$ pada tingkat probabilitas 0,707 . Hasil pengujian diperoleh harga probabilitas hitung 0,707 $>0,05$ atau probabilitas hitung $>$ level of significance $(\alpha)$ sehingga H0 diterima, hal ini berarti bahwa tidak ada pengaruh signifikan dan positif antara (brand awareness $X$ religiousity commitment) terhadap niat pembelian (Y)

\section{PEMBAHASAN}

Dari hasil uji hipotesis 1 dapat diketahui bahwa brand awareness berpengaruh terhadap niat pembelian secara positif dan signifikan, hal ini berarti semakin konsumen mampu mengenali dan mengingat merk roti islami maka niat untuk melakukan pembelian semakin besar. Hal penting yang perlu diperhatikan penggunaan merk Islami berperan dalam meningkatkan kesaradaran merk konsumen mengingat sebagaian besar masyarakat di Indonesia beragama Islam. Adapun dari hasil uji hipotesis 2 dapat diketahui bahwa religiousity commitment berpengaruh positif dan signifikan terhadap niat pembelian, hal ini berarti semakin kuat komitmen religiusitas maka semakin meningkat niat untuk melakukan pembelian. Seseorang yang religious tercermin dapat tercermin pada penerimaan terhadap symbol, nama, bahasa yang dianutnya, sehingga penggunaan merk Islami pada produk dapat mempengaruhi perilaku pembelian dalam hal ini minat melakukan pembelian. Adapun dari hasil pengujian hipotesis 3 bahwa variabel religiousity commitment tidak dapat berperan sebagai variabel moderasi, sehingga pada penelitian ini tidak dapat diketahui religiousity commitment dapat berfungsi 
memperkuat atau memperlemah hubungan pengaruh variabel brand awareness terhadap niat pembelian.

\section{KESIMPULAN}

Berdasarkan penelitian yang telah dilakukan oleh penulis tentang peranan religiousity commitment dalam memoderasi hubungan brand awareness terhadap niat pembelian di toko roti yang mempunyai merk islami di Kota/Kab. Malang maka kesimpulan pada penelitian ini adalah :

1. Brand awareness berpengaruh secara positif dan signifikan terhadap niat pembelian merk produk Islami

2. Religiousity commitment berpengaruh secara positif dan signifikan terhadap niat pembelian merk produk Islami.

3. Religiousity commitment tidak dapat diketahui dapat berperan sebagai variabel moderasi terhadap hubungan brand awareness terhadap niat pembelian merk produk Islami.

\section{SARAN}

Hal penting yang perlu dilengkapi pada penelitian selanjutnya adalah konstruk religiousity commitment. Keluasan konsep religiusitas seharusnya dapat dimplementasikan dalam variabel yang dapat menghasilkan indikator yang lebih kompleks sehingga dapat mewakili konstruk religiusitas.

\section{DAFTAR PUSTAKA}

A, Shimp, Terence (2003). Periklanan Promosi \& Aspek Tambahan Komunikasi Pemasaran Terpadu,Jilid I ( edisi 5), Jakarta Erlangga

Mokhlis, Safiek. 2010. Religious Contrasts in Consumer Shopping Styles: A Factor Analytic Comparison, Journal of Business Studies Quarterly 2010, Vol. 2, No. 1, pp. 52-64

Dharmmesta, Basu Swasta, (2002). Trying To Act: An Empirical Study of Investigating Higher Education Consumers. Gadjah Mada International Journal of Business, Vol 4, No. 1

Delener, N. 1994. Religious contrasts in consumer decision behavior patterns: Their dimensions and marketing implications. European Journal of Marketing, 28(5), 36-53

Esso, Nittin and Dibb, Sally. 2004. "Religious Influences On Shopping Behaviour : An Exploratory Study". Journal of Marketing Management, Vol. 20, PP. 682-712. 
Hoeffler, S., \& Keller, K. L. (2002). Building brand equity through corporate societal marketing. Journal of Public Policy \& Marketing, 21(1), 78-89

Kardes, R Frank. (2001). Consumer Behavior and Managerial Decision Making. Second Edition, Pearson Education Inc. New Jersey

Keller, Kevin Lane, 1993. Conceptualizing, Measuring, and Managing CustomerBased Brand Equity. Journal of Marketing, Vol. 57, No. 1 (Jan., 1993), pp. $1-22$

Liana, Lie, 2009. Penggunaan MRA dengan Spss untuk Menguji Pengaruh Variabel Moderating terhadap Hubungan antara Variabel Independen dan Variabel Dependen, Jurnal Teknologi Informasi DINAMIK Volume XIV, No.2, Juli 2009 : 90-97

Macdonald, E. K., \& Sharp, B. M. (2000). Brand awareness effects on consumer decision making for a common, repeat purchase product: A replication. Journal of Business Research, 48, 5-15

McDaniel, S. W. \& Burnett, J. J. (1990). Consumer religiosity and retail store evaluative criteria. Journal of the Academy of Marketing Science, 18 , 101112.

Mowen, John C and Minor, Michael (2002), "Perilaku Konsumen”, PT. Penerbit Erlangga

Shabbir, Abdullah Alam M. Usman Arshad Sayyed Adnan, (2012),"Brand credibility, customer loyalty and the role of religious orientation", Asia Pacific Journal of Marketing and Logistics, Vol. 24 Iss 4 pp. $583-598$

Sandikci, Ozlem and Ger, Güliz, 2011. Islam, Consumption and Marketing: Going Beyond the Essentialist Approaches. Handbook of Islamic Marketing, Ozlem Sandikci and Gillian Rice, eds., Edward Elgar.

Sood, J. \& Nasu, Y. (1995). Religiosity and nationality: An exploratory study of their effect on consumer behaviour in Japan and the United States. Journal of Business Research, 34, 1-9

Vitell, Scott, J. 2009. "The Role of Religiosity in Business and Consumer Ethics: A Review of the Literature". Journal of Business Ethics , Vol. 90, PP. 155167

Worthington, E. L., Wade, N. G., Hight T. L., Ripley, J. S., McCullough, M. E., Berry, J. W., Schmitt, M. M., Berry, J. T., Bursley, K. H., \& O’Connor, L. (2003). The religiousity commitment inventory-10: Development, refinement and validation of a brief scale for research and counselling. J. Couns. Psychol., 50, 84-96 